\title{
ПАНТЕИСТИЧКО РАСКАЖУВАЧКО ИСКУСТВО (ВО СВЕТОТ НА ЗООСТОРИИТЕ ОД ВЛАДИМИР МАРТИНОВСКИ)
}

\author{
Искра Тасевска Хаџи-Бошкова \\ Универзитет „Св. Кирил и Методиј“, Скопје \\ iskra.tasevska@flf.ukim.edu.mk
}

Традиционалните и современите наратолошки истражувања ја потврдија виталната природа на раскажувањето и неговото значење за правилно разбирање на речиси сите човечки феномени. Таквата фокусираност врз човекот и неговата способност за раскажување ги поттикна актуелните анализи кон промислување на природата на другите појави (од човечкиот, животинскиот, растителниот свет и сл.), кои поседуваат сопствен животен тек и своја приказна. Во таа смисла, импресивната творечка објава на Зоостиориииее од Владимир Мартиновски значеше своевиден културен пресврт во македонската средина, преиспитувајќи ги темелните својства на раскажувањето. Оваа збирка ја имагинира зоосферата како специфичен хронотоп, среде кој се преобликуваат мноштвото актуелни категории, кои се дел од човековата постмодерна култура. Истовремено, таквото конципирање на различните приказни од животните и за нив, кои не само што добиваат право на глас туку израснуваат и како активен творец, значи поместување на метафизичкиот картезијански центар, кој со векови ја затемнува суштествената улога на природната разновидност при промислувањето на човековата суштина. Да се пишува туѓата приказна значи да се согледа себството како некој Друг, односно да се надмине она што разликува во корист на она што создава просторни односи и временска блискост (во смисла на поимот différance на Жак Дерида).

Клучни зборови: раскажување, зоосторија, македонска литература, Владимир Мартиновски, постмодернистички расказ 


\title{
PANTHEISTIC NARRATIVE EXPERIENCE (IN THE WORLD OF ZOO STORIES BY VLADIMIR MARTINOVSKI)
}

\author{
Iskra Tasevska Hadji Boshkova \\ Ss. Cyril and Methodius University, Skopje \\ iskra.tasevska@flf.ukim.edu.mk
}

Traditional and contemporary narratological examinations have underlined the vitality and primordial nature of narration as a key point for proper understanding of almost all human phenomena. Philology as a science puts the focus of its study primarily on human creatures and their ability to narrate. However, recent analyses provoke questions about other phenomena in nature (regarding humans, animals, plants etc.), especially because they all possess a unique life span and life stories. In that sense, the impressive work Zoo Stories by Vladimir Martinovski represents a kind of cultural revolution in the Macedonian literature, re-examining the presupposed nature of human narration and its attributes. These stories represent the zoosphere as a specific chronotope, i.e. a platform where all the current categories of human postmodern culture are being revalorized. This kind of story construction, originating from the animals and dedicated to them, enables their transformation into active authors and undermines the metaphisically defined Cartesian subject (which overshadowed the role of natural diversity regarding human essence and existence). Hence, to write the story of "the Other" underlines the necessity to see oneself as other, or to overcome the simple difference in favour of the spatial and temporal relations (considering the notion "différance" by Jaques Derrida).

Keywords: narration, animal story, Macedonian literature, Vladimir Martinovski, postmodern short story 


\section{1 Феноменот раскажување како уметничка фасцинација}

Природата на раскажувањето, кое е специфичен творечки процес, претставувала предмет на интерес на човештвото од најраните времиња. Од една страна, тоа ја отсликува неминовната потреба на човекот за промислување на животот воопшто, но и неговата исклучителна посветеност на разбирањето на феномените, кои ја овозможуваат спекулацијата на внатрешниот живот. Литературната наука отсекогаш се занимавала со поимањето на поетскиот и на прозниот израз како одделни феномени, кои треба доследно да се истражуваат. Еден аргумент во тој контекст е, на пример, специфичната поставеност на хеленската лирска поезија наспроти огромното поле на епската поезија од тоа време (осмиот, односно седмиот век пр. н. е.). Како што забележуваат критичарите (Budelmann 2009: 5), едно од можните објаснувања за тешкото издвојување на лириката од составот на другите видови текстови се должи на фактот дека во фокусот на западноевропските книжевнотеориски истражувања (кои првенствено се поврзуваат со Аристотеловата Поейика) е поставено раскажувањето како феномен (Аристотел 1979: 21). Тој факт може да се забележи особено во Аристотеловото сопоставување на епот и трагедијата, како едно од најактуелните прашања, како и преку Платоновите согледувања што претходат (Платон 2005: 23-25), а кои ја истакнуваат специфичната поставеност на дитирамбот како чист раскажувачки жанр.

Промислувањата за доминантноста на раскажувањето како феномен во западноевропската цивилизација наоѓаат поткрепа и во истражувањата од следните епохи, особено во времето на романтизмот. Во фокусот на тогашните поимања на човековата творечка инвенција се, секако, претпоставките за лириката како една древна фаза во развојот на литературното творештво, но и во еволуцијата на човештвото воопшто. Како што истакнува Виктор Иго во предговорот кон драмата Кромвел (Hugo 1979: 317), отелотворувањето на првите творечки обиди на човештвото се реализира, пред сѐ, во лирските форми на изразувањето (химната/одата, односно молитвата како нивна религиска варијанта). Тоа родовско, претколективно чувствување на светот е дополнето со анимистичкото или ранорелигиско конципирање на божественото, кое во свеста на творецот поттикнува формулирање на облици со кои се овозможува комуникацијата на човекот со повисоките сфери на постоењето. На тоа се надоврзува етапата на формирањето на поголемите заедници и нации, која е обележена со доминантното епско чувствување на животот и колективот, како и со специфичната етичко-естетска поставеност на човекот во светот. Модерните времиња, според Иго, се целосно драмски, бидејќи тие го потцртуваат неминовното внатрешно проникнување на различните сопоставени и противречни категории и вредности. И покрај природата на оваа класификација, која ја потцртува тројната поделба (која, пак, ќе биде општо место во подоцнежните категоризации), во визијата на Иго избива во преден план доминантноста на раскажувачката визура во епиката, но и нејзиното присуство во затскриен облик во драмското творештво. 
Токму во духот на (пост)модернистичкото чувствување на преплетеноста на различните феномени на творењето и постоењето, во македонската културна средина во 2019 година се појави несекојдневната и исклучителна книга од македонскиот писател и универзитетски професор Владимир Мартиновски, под наслов Зоостиории. Таа во себе импрегнира различен вид (рас) кажувања и прикажувања, кои ги поставуваат под прашање строгите жанровски разликувања и претпоставки. Тие текстови се исполнети со специфична творечка фасцинација од доживеаните и искусени феномени, клонејќи кон длабоко духовно проникнување во суштината на постоењето воопшто. Оваа специфичност на делото на афирмираниот македонски автор го забележува и Томислав Османли, кој заклучува: „Така, патот на седумдесет и седумте раскази и на циклусите од по седум прози на Владимир Мартиновски, е пат на едно земно, поетичко, немистицистичко чудење над необичните својства на светот“" (Османли 2019: 205). Иако делото го поставува читателот навидум пред дилемата за трагање по невообичаените симболични феномени, преточени во „строгата“ конструкција (единаесет циклуси што врамуваат по седум раскажувања), таа рамка, всушност, го мотивира читателовото внимателно забележување на трансгресивната природа на овој творечки потфат. Тоа значи дека во сржта на вербалните феномени се поставени прашањата за жанровските форми и нивното бесконечно вмрежување, кое во овој случај го засилува и го трансформира естетскиот резултат и читателското искуство. Читателот е предизвикан да трага по суптилните нијанси на животот околу него, кој се манифестира низ изобилството од појавите во човечкиот, во животинскиот и во растителниот свет. Тие ја потцртуваат потребата да се надминат дарвинистичките претпоставки за да се сфати специфичната (духовна) поврзаност на сите нешта во светот.

\section{2 Зоосторијата среде литературните категории и феномени}

Истражувањето на начинот како наративот го рефлектира појавниот свет, кој не е нужно (и исклучиво) човечки, особено кога како раскажувачи се појавуваат другите живи суштества, во современието претставува несомнен интерес на одредени литературнокритички студии, поврзани со екологијата и биодиверзитетот воопшто. Како што забележува Брајан Меккормак за студијата на Деј-

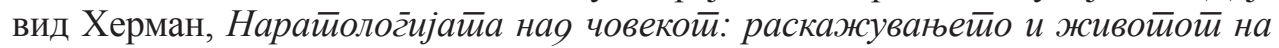

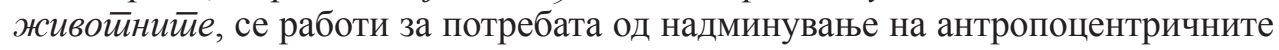
наратолошки и културолошки концепти, кои ја попречуваат визијата на Другиот (McCormack 2018: 1). Притоа, чувствувањето, односно сочувствувањето, како врвно духовно искуство на човекот, кое треба да доведе до менување на доминантната перспектива и постулирање на „трансвидовата екологија на себствата“, е единствената алатка со која човекот може да го доживее светот во неговата целокупна разновидност. Во таа смисла, жанрот „зоосторија“, онака како што го постулира Владимир Мартиновски, терминолошки и структурно претставува специфично отелотворување на пантеистичкото чувствување на животот во неговата целосност. Тој жанр импресивно ги варира различните прозни и поетски вербални шаблони, вметнувајќи мноштво различни култур- 
ни и цивилизациски сознанија, сѐ со цел да создаде една сеприсутност во форма на транслитерарност и трансмедијалност. Со својата импрегнираност, таа форма потсетува дека животот е, и покрај неговата комплексност, во суштина, мошне едноставен, особено кога ќе се спознае низ спектарот на разновидните појави и процеси.

Обидувајќи се да направиме синтеза од различните пристапи што ги користи авторот Мартиновски за да го изрази незапирливиот творечки потенцијал на зоосторијата, би требало најпрво да го забележиме варирањето на литературните техники. Понирајќи во длабочината на раскажувачката структура, во расказот „Сафари на доктор“ Мартиновски ја преобликува веројатноста на раскажаните настани (сѐ што се случува е прекршено низ свеста на заспиениот пациент, кој во прво лице раскажува за своето необично искуство во текот на операцијата). Од друга страна, под прашање се поставени одредени концепти, од типот на природата на вметнатата приказна, која во суштина, го следи образецот на текот на свеста, симулирајќ и филмска брзина на настаните. Двете приказни (врамувачкиот раскажувачки контекст и раскажаната приказна за докторот што ја злоупотребува својата професија), се спојуваат во точката каде што, преку „трчањето во сонот“, се внесува фантастичниот момент - „нешто сепак ми вели дека ќе ме има во Црна хроника како дел од уловот“ (Мартиновски 2019: 12). На сличен начин во расказот „Еж без игли“ сме соочени со искуствата на раскажувачот, кој во случајов е жена, но тие негови доживувања се преточени како директно пренесени искази на околните пациенти, кои се третираат во ординацијата за акупунктура. Заднината врз која се проектираат постапките што се применуваат во оваа древноисточна медицинска процедура создава простор во кој се изневеруваат правилата на физичкиот свет (особено неговите временско-просторни димензии). Поради тоа, читателот е соочен со бескрајната симултаност на различните вербални и мисловни шаблони. Така, во форма на еден уметнички дијалогизам (кој, притоа, ја надминува и ја негира формалната страна на дијалогот), се мешаат свестите на шивачката, измамениот брат, детето, вработениот во приватниот сектор, хронично болниот, фобичниот, но и на оној општествено совесен човек, кој страда поради тешката состојба во која се наоѓ обичниот граѓанин. Овој расказ ги актуализира современите животни проблеми, оние со кои луѓето од 21 век постојано се соочуваат, алудирајќи на македонската општествена стварност и критикувајќи ја. Соодветно на тоа, интертекстуалноста во овој расказ израснува на рамниште на интермедијалност (видлива во алузијата на Бројгеловото отсликување на суровата „стварност“, во која луѓето не се грижат за падот на Човекот). Така и игрите со зборови го релативизираат не само значенскиот универзум туку и валидното преплетување на различните културни парадигми, кои доведуваат до суштинско меѓукултурно разбирање. „Кога, облечена, насмеанион доктор со раче путер ќе ме праша дали ми е подобро, веројатно ќе му речам 'Јес, бетер!‘ Ама сега сепак знам дека на другите околу мене им е бетер“ (Мартиновски 2019: 29).

Следејќи го раскажувачкиот дискурс на Мартиновски, во неговите дискретни нијанси можат да се забележат многубројни експлицитни и имплицитни промислувања за природата на уметноста и уметничкото создавање 
воопшто. Прашањето за бесконечната симултаност и случајност, која на невидлив начин го раководи животот, е поставено во врска со спојот од необични ситуации, кои бесконечно се преплетуваат. Така, во расказот „Крпа скакулец“, баналниот факт дека две жени ќе имаат ист фустан на свадбата на која ќе одат е иронично потцртан преку необичното откритие што се случува, ни помалку ни повеќе, преку телевизискиот екран! Таа симултаност и конвергенција на различните појави и настани кулминира со губењето на крпата, која како скакулец исчезнува од искуствениот свет за да се појави во светот на уметноста. Бесконечното удвојување на животот и уметноста, кое води кон губење на нивните јасни граници, го реактуализира прашањето за веројатното и можното. Веројатноста на раскажувањето, односно неговата условеност од причинско-последичните врски (Chatman 1978), во овој случај значи бесконечно преплетување на дискретните моменти, кои ја условуваат појавата на следниот раскажан контекст. Во таа смисла се индикативни последните три реченици од расказот, кои ја потцртуваат специфичната природа на вербалната уметност и нејзиниот однос кон стварноста: „, - Глупости - си велам - и пак го менувам каналот. Но, и тука има 'ударни вести'. Ја даваат мојата слика““ (Мартиновски 2019: 10).

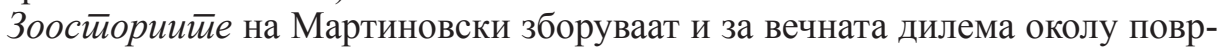
заноста на појавниот/искуствениот и уметнички преобликуваниот „можен“ свет, кој како „паразит на реалниот свет“ (Еко 2005: 102) постојано нѐ води кон несвесно прифаќање на неговите правила на игра. Така, во расказот „Бубамара на зрно калинка“, уметноста со својата субверзивна природа во однос на искуствените концепти и вредности ја поткопува дури и најнаивната желба на човекот едноставно да ја реализира сопствената судбина, задирајќи во природата на меѓучовечките односи. Срамежливата и наивна вљубеност на момчето во девојката од студиото за тетовирање него го води кон активно и креативно преобликување на интимниот конфликт, кој кулминира со неговото буквално, телесно изложување среде Музејот за современата уметност, наместо неговата „скулптура од 'раната фаза'“. И покрај длабоката пародичност што ја носи вака конципираната ситуација, нејзината хумористична страна е затемнета со благата носталгија по изгубената, но сепак, веројатна можност за човечка срдечност и блискост.

Спрегата на животот и уметноста во одредени раскази израснува и до нивото на една бесконечна хибридизација на сѐ што е искуствено, како дел од физичката стварност, која низ различните појави непрестајно се трансформиpa. Во расказот „За мене е морж“, среде непрестајните прошетки по Аргентина се трага по изненадувањето од јапонската зен-градина. Таа индиректно влијае и на природата на овој расказ, кој го добива обликот на јапонскиот жанр, претворајќки се во „аргентински коан“. Наслушнувањето на разговорот на дедото и девојчето, пренесен веродостојно, кој дополнително ја хибридизира жанровската структура (бидејќи се појавува во форма на хаику), уште еднаш ја промовира идејата за уметноста како повиско спознание од и за животот. „- Дедо, види морж! / Не е морж, туку дабар! / За мене е морж!“ (Мартиновски 2019: 128). Уметноста е живот и животот е уметност, секогаш низ 
удвојување и трансформирање на привидноста на сетилниот живот („Островот на змиите“, „Островот на камелеоните“).

\section{3 Раскажувањето како врвна интерсубејктивност}

Анализирајќи ја природата на дискурсот како недвосмислена и дискретна размена на искуства и мисловни концепти, филолошко-философските промислувања (Bahtin 2000, Benvenist 1975, Кристева 2003) го реактуализираа концептот на интерсубјективноста, сфатен како нужна сопоставеност и реверзибилност на себството (субјектот) и Другиот. Тој феномен детално се промислува во редица од расказите за и од животинскиот свет на Мартиновски, кои ја потенцираат мистичната источна претстава за поврзаноста на сите нешта во светот. Расказите формулираат едно специфично пантеистичко искуство, афирмирајќи го животворниот дух на нештата и појавите што се дел од нашето секојдневие, со што недвосмислено се отвора можноста за нивно „онеобичување“, кое допира и до надреалистичкиот идеал за „,автоматското пишување“. Фасцинантен пример за интерсубјективноста, која добива длабоко духовни размери, е расказот „(Авто)портрети“, кој со својата конструкција моментно ни асоцира на кубизмот и неговата креативна мешавина од појавности. Тоа е манирот во кој следува раскажувањето за тројцата шпански сликари, кои постепено, фокусирајќи се на моделот што служи како нивна творечка мотивација, почнуваат да се трансформираат на еднакво креативен начин.

Па така, симултаното дезертирање на моделите миленици, остави трајни бразди врз историјата на уметноста: првиот сликар, тоа јулско утро одлучи да пушта мустаќи, а и долгорочно да се посвети на темата на преобразбата меѓу човечкото и анималното. Вториот сликар од тоа утро папагалски им се посвети на арлекините, циркузантите, веселниците и на суштествата за кои никогаш не си сигурен дали се луѓе или животни, насликани со спектарот на бои од перјата на своето милениче. Третиот сликар, со лојалност на пес, одлучи да се слика себеси и сите свои љубови како што тоа јулско утро случајно почна да го слика својот заспан најдобар пријател (Мартиновски 2019: 48).

Карневалската мезалијанса и измешаноста на различните тонови и акценти (Bahtin 1978), која под привидот на разовидноста на појавите, всушност, ја потцртува гротескната единственост на хетерогените елементи, особено се забележува во расказот „Јагнешка опера“. Тука фантастичната преплетеност на мноштвото чинители, кои добиваат своја древномитолошка заднина (поврзаноста на животинските и човечките фигури во египетскиот пантеон), го отелотворува карневализираниот времепростор, во кој оперската пејачка и спасеното јагне доживуваат меѓусебни преобразби, разменувајќи си ги својствата и вредностите. Во таа смисла е мошне индикативен и расказот „Филиз и Дениз“", кој ја користи културната заднина (асоцијацијата на турската култура и нивните серии) како основа за отсликување на специфичната духовна релација меѓу девојката и делфинот. Во овој случај сложеното прашање за идентитетот на одреден лик се одговара преку непрестајната варијација на 
конгруентноста на сите животни феномени, која допира дури и до проблемот на постоењето и смртта. „- Можеби нема да ми верувате, ама таа умрела во истиот миг кога и Дениз. Баш во истиот миг. Како некој одеднаш да ги прободел. И двајцата во ист миг. Со оние големине копја изложени во Топкапи“ (Мартиновски 2019: 64). И покрај тоа што во повеќето раскази е мошне актуелен контекстот, односно оние културни детерминации што се втемелени во природата на секој опишан регион, импресивни се примерите каде што таквите одредници се подложени на бесконечно варирање. Тоа само покажува дека светската култура е еден незапирлив тек, во кој се прекршуваат и се преплетуваат мноштвото традиции, без потцртување на привидната доминантност или исклучивост на еден регион во однос на друг. Тоа може особено да се забележи во расказот „Пес исцелител“, во кој среде сензибилната и лиризирана атмосфера се спојуваат источниот хаибун (како и неговите поетски и прозни својства) со јужноамериканското искуство на лечење (преку грдото и неугледно куче Олајтантамбо).

Аналогно на природата на жанрот зоосторија, кој ја потцртува феноменолошката сеприсутност на сите разноликости на животните појави, одредени раскази во оваа збирка го актуализираат прашањето за релацијата на овој жанр со неговиот најблизок антички соодветник, а тоа е басната. Како што забележува Сашо Огненовски (Огненовски 2020), расказите во оваа збирка ,, (...) се еден вид антитеза на басните. Не, секако овие раскази немаат амбиција да бидат басни, тие дисперзираат реалитет кој не подучува, туку предупредува“. Во суштина, ние сметаме дека одредени циклуси во оваа збирка, како што се циклусите „Зоомонолози“ или „Ентомонолози“, ја рефлектираат природата на постмодернистичкото „двојно кодирање“ (Џенкс 2006: 162), кое ги користи традиционалните форми и наследството како подлога, врз која може да се проектираат модерните облици на изразување и моделирање. Во тој контекст проблеснува нивната автентичност и инспиративност, која ја рефлектира низата од алегориски трансформации, со цел од неа да избликне огромниот креативен потенцијал на постмодерниот расказ. Таа вештина на обликување придонесува да се активира целиот состав од мисловни концепти, кои бараат да се промисли, на пример, тезата за разочараноста на папагалот од ситуацијата на која го осудило човештвото („На раат“). Секако, појавата на животните како раскажувачи, односно главни ликови, во дел од расказите поттикнува интерпретација што го следи алегорискиот дискурс и неговата природа. Од друга страна, алегоријата мотивира и промислување на специфичната поставеност на Другиот, оној што е нужен, но сепак, запоставен во непрестајната интерсубјективна корелација.

Впечатокот што го предизвикува раскажувањето на овие приказни подразбира потреба од негово преиспитување, првенствено во врска со нужните категории што ги втемелува. Релативноста на формалната разлика меѓу кратките и долгите раскажувачки форми го актуализира прашањето за границите и можностите за составување расказ што ќе се состои од само една реченица. Својствата на раскажувањето, кои ја рефлектираат бесконечната метафорична сродност на различните појави и процеси, Мартиновски ја преиспитува во циклусот „Зоореченици“. Во него е потцртана сличноста меѓу навидум раз- 
нородните феномени: предењето на мачорот Милорад и она на фрижидерот, дискретниот еуфоничен квалитет на именувањето, гротескната хомонимија меѓу сандакот за замрзнување и оној што се користи за погребување, носталгичните сеќавања среде хаотичната состојба на биодиверзитетот и сл.

\section{Рибино масло}

Од сите масла што минале низ нашите стомаци, повеќето ги забораваме, ама не и маслото од раните детски утра, маслото што го голтавме ко под казна, за да растат нашите коски, а и да се намалуваат нашите настинки и кашлици, маслото што го голтавме со згрчени гримаси, со затнат нос и понекоја солза, со надеж дека бргу ќе следува и лажичка мед, маслото што сѐ уште продолжува да плива во нашите стомаци (Мартиновски 2019: 169).

\section{4 Зоосторијата како сатира и одговор на општествените предизвици}

Зоосторијата се актуализира како мошне креативно и моќно средство, особено кога станува збор за разбивање на системот на општествена контрола и расветлување на проблемите од секојдневнието. Расказите од овој вид го заведуваат читателот со својата специфична структура, па тој чувствува нестивната потреба нивните својства да ги расветли во контекст на сродните жанрови. Сепак, искусниот читател мора да биде свесен за паратекстуалното упатување што го дава авторот, укажувајќи на фактот дека зоосториите се „приказни за луѓe и животни“. Ваквото определување ја потврдува специфичната феноменолошка поставеност на зоосторијата како граничен жанр, кој не би можел да се класификува во постојниот жанровски систем и ред, без притоа да ги допре лиминалните подрачја на различните „зацртани“ жанрови. Оваа пречекорувачка (трансгредиентна) природа на овие приказни може да се илустрира низ неколку примери. Во расказот „Чекајќи го Никос“, раскажувачот нѐ водедува во една исклучителна авантура, која се случува на островот Крит, кој, пак, во нашата свест го актуализира и модерното и античкото. Верноста на кучката, која долго време го чека стопанот да се врати, дури и по неговата смрт, токму пред продавницата каде што тој секогаш пазарувал, израснува како симбол среде интертекстуалните релации што ги постулира раскажувањето. Во суштина, една поразвиена интерпретативна стратегија недвосмислено ќе го поврзе името на кучката Клио со музата на историјата, откривајќи ја истовремено акумулирачката природа на историјата, која ја прикажува расказот. Историјата се храни, буквално и метафорично, од остатоците со кои само преживува, чекајќи уште долго време пред продавницата, која е одамна затворена, сведочејќи за неизбежното одминување на времето.

Специфичната интеракција на луѓето и животните во ткивото на раскажувањето претставува можност за најразлични текстовни варијации. Во расказот „Канон“, првичната претпоставка што се создава во свеста на читателот (за тоа што значи зборот „канон“) се преобликува среде мистичноста на храмот во Камбоџа, кој привлекува мноштво туристи. Тој сведочи за една необична коегзистенција на луѓе и животни (мајмуни), кои и покрај својата еволутивна 
блискост (како што упатува и самиот раскажувач) се наоѓаат во притаен конфликт, првенствено поради инстинктивниот нагон за себеодржување. Таа навидум обична ситуација, која сведочи за гневот на туристот поради украдениот фотоапарат, во суштина ја потенцира безнадежноста и духовната празнина на современиот човек, кој поради окупираноста со потребата „да го фати“ моментот не ја забележува импресивната претстава во храмот, поврзана со наративот од Рамајанайа. Тој необичен судир на современите вредности и традицијата израснува на ниво на спротивставување меѓу стварноста, која е мултиплицирана на повеќе нивоа, и симулакрумот што ја рефлектира (Бодријар 2001), станувајќи повалиден дури и од „оригиналот“. Во таа смисла, расказот „Јазовци на војната““ го реактуализира проблемот на потрагата по туристички, комерцијални фасцинации по виетнамските тунели од војната, која ги доведува ликовите во животна опасност. Влогот е голем, бидејќи таа авантура ќе може да се раскажува надолго и нашироко, но тоа не ја поништува потребата наративот да формулира и директно предупредување: „Додека ползат како јазовци, гонети од некој гладен предатор и двајцата во ист миг посакуваат нивните блиски и далечни потомци никогаш да не мораат да ја вкусат војната на своја кожа“" (Мартиновски 2019: 77).

Светот на зоосторијата, кој во себе импрегнира мноштво чинители, недвосмислено ја потенцира потребата од надминување на едноставните констатации за природата на раскажувањето. Нејзиниот хибриден карактер покажува дека е таа понекогаш активна критика на современите начини на живеење и нивните импликации („Смена“, „Дуќан за миленици“), а другпат само навидум едноставно разбирање на постоењето на живиот свет, кој ги живее морално-етичките вредности и ненадминатите древни еволуционистички претпоставки („Ручек“, „Прошка“). Сепак, она што дефинитивно ја прави оваа нарација специфична во однос на огромното наследство од текстови е нејзината активна претпоставка за преплетеноста на различните рамништа на егзистенцијата, односно на различните светови, кои во ниеден случај не се самодоволни ниту можат да се поништат меѓусебно. Во тој контекст се мошне парадигматични расказите „Адам и Ева“ и „Утрински повик“, кои ги активираат наследените културни и традиционални концепти во функција на создавање на една проширена визија за животот и постоењето воопшто.

\section{Библиографија}

Аристотел. (1979). Поеӣика. Скопје: Македонска книга, Култура, Наша книга. Бодријар, Ж. (2001). Симулакруми и симулаиија. Скопје: Магор.

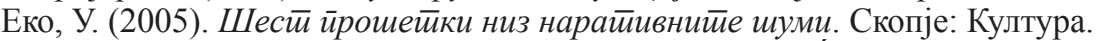

Кристева, J. (2003). Речта, дијалогот, романот. Во К. Куулавкова (прир.). Теорија на

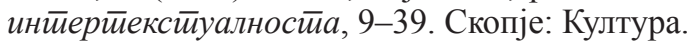

Мартиновски, В. (2019). Зоосйории (Приказни за луѓе и живойни). Скопје: Бегемот. Османли, Т. (2019). Зошто „Зоостории“"? (Поговор кон Зоостории од Владимир Мартиновски). Во Владимир Мартиновски. Зоосиоории (Приказни за луг̌е и живойни), 204-211. Скопје: Бегемот. 


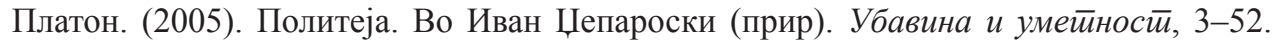
Скопје: Магор.

Џенкс, Ч. (2006). Од „Што е постмодернизам?“ (1986). Во Лоренс Кахун (ур.). Оو мояернизам яо йосӣмояернизам, 161-176. Прев. Драган Јакимовски. Скопје: Темплум.

Bahtin, M. (1978). Stvaralaštvo Fransoa Rablea i narodna kultura srednjega veka i renesanse. Prev. Ivan Šop i Tihomir Vučković. Beograd: Nolit.

Bahtin, M. M. (2000). Problemi poetike Dostojevskog. Prev. Milica Nikolić. Beograd: Nolit.

Benvenist, E. (1975). Problemi opšte lingvistike. Prev. Sreten Marić. Beograd: Nolit.

Budelmann, F. (2009). Introducing Greek Lyric. In Felix Budelmann (ed.). The Cambridge Companion to Greek Lyric, 1-18. Cambridge: Cambridge University Press.

Chatman, S. (1978). Story and Discourse (Narrative Structure in Fiction and Film). Ithaca and London: Cornell University Press.

Hugo, V. (1979). Predgovor „Cromwellu“. U Miroslav Beker (prir.). Povijest književnih teorija, 316-332. Zagreb: SNL.

Огненовски, С. (2020). Комплексна зоо симбиоза (Кон збирката раскази „Зоостории“ на Владимир Мартиновски во издание на Бегемот, Скопје, 2019). [Интернет] Крuишика. Достапно на: https://kritika.mk/kompleksna-zoo-simbioza/ [Пристапено на 20.8.2020]

McCormack, B. (2018). Narratology beyond the Human: Storytelling and Animal Life by David Herman. [Online] The Goose, vol. 17, no. 1, 1-3. Available from: https://core. ac.uk/download/pdf/216874576.pdf [Accessed: August 20 ${ }^{\text {th }}, 2020$ ] 
